Islamijah: Journal of Islamic Social Sciences

Vol. 1, No. 1 (2020), pp. 1-25, Doi : 10.30821/islamijah.vli1.7155

\title{
ULAMA MANDAILING AWAL ABAD KE-20: Gerakan Religius dan Politik Abdurrahman Sjihab (1910-1955)
}

\author{
Ja'far \\ Universitas Islam Negeri Sumatera Utara Medan \\ Jl. Willem Iskandar Pasar V Medan Estate, Sumatera Utara, 20371 \\ e-mail: jafar@uinsu.ac.id
}

\begin{abstract}
Mandailing Ulama at the Beginning of the $20^{\text {th }}$ Century: Abdurrahman Sjihab's Religious and Political Movement (19101955). This study aims to examine the religious and political movements of Abdurrahman Sjihab. This study utilizes written sources that are then analyzed by content analysis methods. Despite the important role played by Abdurrahman Sjihab as one of the leaders of the Islamic religion who fought at the local and national level as a freedom fighter for the Republic of Indonesia, there has not been a study that covers his biobiography. This study finds that Abdurrahman Sjihab contributed to the efforts to fight, defend and contribute to the independence of the Republic of Indonesia. In the socio-religious field, he and his colleagues founded Al Jam'iyatul Washliyah, which is engaged in education, preaching and social affairs, and this effort was relatively successful in preparing militant Muslim resources. In the social political field, he on behalf of AI Washliyah fostered relations and established coordination with Islamic leaders at the local and national levels in the context of fighting for and filling Indonesian independence, and for this reason he became a Masjumi politician, a member of the Central Indonesian National Committee (KNIP) and member of the Provisional People's Representative Council (DPRS). This study is expected to nurture the biographical treasures of Muslim figures in the early days of Indonesian independence.
\end{abstract}

Keywords: Abdurrahman Sjihab, Al Washliyah, Masjumi, East Sumatra 
Islamijah: Journal of Islamic Social Sciences, Volume 1, Number 1, January 2020: 1-25

\section{Pendahuluan}

Ada banyak tokoh yang berdedikasi bagi agama dan negara di Indonesia, tetapi gerakan dan pemikiran mereka tidak terekam secara baik. Dalam kasus Provinsi Sumatera Utara, ada banyak tokoh lokal yang kemudian berkiprah secara nasional. Di antara mereka adalah M. Arsjad Thalib Lubis, Musthafa Husein, Salim Fachry, Tengku Fachroeddin, Zainal Arifin Abbas, Fuad Said, Ismail Banda, Adnan Lubis, Udin Sjamsuddin, dan Abdurrahman Sjihab. Tentu saja, mengenal kehidupan dan pemikiran mereka dinilai penting dalam rangka mencari pelajaran berharga yang bisa dipetik dan meneladani kebaikan-kebaikan yang mereka torehkan. Menelaah tokoh-tokoh lokal tersebut tentu sangat menarik dilakukan.

Abdurrahman Sjihab tentu saja memiliki keunikan tersendiri. Tidak banyak tulisan mengenai ulama ini. Padahal, ia merupakan salah satu tokoh Masjumi pada level lokal dan nasional dan pendiri Al Jam'iyatul Washliyah yang merupakan salah satu organisasi Islam terbesar di Indonesia. Salah satu faktor mengapa tidak banyak tulisan mengenai ulama ini adalah sedikitnya sumber-sumber tertulis mengenai biografinya atau juga langkanya karya-karya yang ditulisnya. Memang, Abdurrahman Sjihab pernah menulis riwayat hidupnya sendiri tetapi sayang sekali karya autobiografinya tersebut masih belum diterbitkan.

Sejarah kehidupan Abdurrahman Sjihab setidaknya pernah ditulis dalam tujuh buku yang berjudul Kami Perkenalkan (1954), Peringatan Al Djamijatul Washlijah 1/4 Abad (1956), Sejarah Ulama-UlamaTerkemuka di Sumatera Utara (1983), AlJam'iyatul Washliyah 1930-1942: Api Dalam Sekam di Sumatera Timur(1988), Thabaqatus Syâfi iyah: Ulama Syâfi 'i dan Kitab-kitabnya dari Abad ke Abad (2011), Biografi Ketua Umum Pengurus Besar Al Jam'iyatul Washliyah 1930-2015 (2015a) dan Tradisi Intelektual Al Washliyah (2015c). Ketujuh buku ini menjadi gerbang utama untuk

mengetahui sosok Abdurrahman Sjihab ditambah tulisan-tulisan yang diwariskannya meskipun belum semua karyanya ditemukan.

Fokus tulisan ini adalah mengungkap gerakan religius dan politik Abdurrahman Sjihab. Secara metodologis, studi ini merupakan studi sejarah (historical research), khususnya sejarah individu, yang menurut Kuntowijoyo (2013), "sebagai kekuatan 
sejarah dan mengubah sejarah" (h. 106). Kuntowijoyo menjelaskan bahwa ada lima tahap dalam penelitian sejarah: pemilihan topik, pengumpulan sumber, verifikasi (kritik sejarah, keabsahan sumber), interpretasi (analisis dan sintesis), dan penulisan (Kuntowijoyo, 2013). Terkait sumber, tulisan ini akan memanfaatkan sumber-sumber primer dan sekunder saat membahas gerakan religius dan politik Abdurrahman Sjihab. Sumber-sumber primer tersebut adalah karya-karya yang ditulis oleh Abdurrahman Sjihab baik berbentuk buku maupun artikel. Sedangkan sumber-sumber sekunder dimaksud adalah buku atau artikel yang berkaitan dengan tokoh ini. Kajian ini merupakan studi biografi di mana akan dikaji gerakan Abdurrahman Sjihab dalam bidang keagamaan dan politik. Data penelitian akan dianalisis dengan metode analisis isi. Studi ini merupakan studi awal tentang ulama Mandailing yang berjuang untuk memajukan Islam dan masyarakat Muslim di Indonesia serta merebut dan mengisi kemerdekaan melalui jalur politik.

\section{Latar Belakang Kehidupan}

Abdurrahman Sjihab merupakan tokoh yang berasal dari etnis Mandailing. Ia bermarga Rangkuti. Ahmad Faisal AR Syihab (2018) pernah mengatakan bahwa Sjihab bermarga Parinduri. Akan tetapi, salah seorang puteri kandungnya menguatkan bahwa ia bermarga Rangkuti. Ayahnya bernama H. Sjihabuddin, seorang kadi di Kerajaan Serdang dan bertugas di Kampung Paku, Galang, Kerajaan Serdang, Keresidenan Sumatera Timur. H. Sjihabuddin bin Jamanggis menikah dengan Hj. Tupin binti Lebai Karim (Hasanuddin, 1988). Mereka dikaruniai sejumlah anak di antaranya Abdurrahman Sjihab, Bahauddin Sjihab, Zakiah Sjihab, Umar Sihab dan Abdurrahim Sjihab (wawancara dengan Ahmad Faisal AR Syihab 2018; Fatimah Zahara, 2018).

Abdurrahman Sjihab lahir di Kampung Paku, Galang (sekarang bagian dari Kabupaten DeliSerdang) pada tahun 1910. Dahulu, kawasan ini merupakan wilayah kekuasaan Kerajaan Serdang, sebuah kerajaan Melayu. Tentu saja, sebagai orang Mandailing, Kerajaan Serdang bukan daerah asal keluarganya. Tetapi, ayahnya mendapatkan kedudukan terhormat karena dipercaya sebagai Kadi Kerajaan di Kampung Paku. Dari sisi ini, Sjihab merupakan ulama nasab, 
Islamijah: Journal of Islamic Social Sciences, Volume 1, Number 1, January 2020: 1-25

artinya bahwa ia adalah keturunan ulama, atau setidaknya anak dari tokoh agama di daerah kelahirannya. Di Sumatera Timur, beberapa ulama, termasuk dalam lingkungan organisasi Al Washliyah, bukan merupakan ulama nasab.

Sebagai anak tokoh agama, Abdurrahman Sjihab mendapatkan pendidikan agama secara informal dan formal. Pada tahun 1918 sampai 1922, ia belajar di Maktab Sairussulaiman di Simpangtiga Perbaungan (sekarang bagian dari Kabupaten Serdang Bedagai). Tetapi, ia juga mengenyam pendidikan umum di mana ia mendapatkan pelajaran umum di sekolah Gubernement. Menurut Muaz Tanjung (2018), ia melanjutkan pendidikan agamanya di Maktab Islamiyah Tapanuli (MIT) untuk tingkat menengah ke atas (Qismul 'Aly). Waktu itu, MIT dipimpin oleh Syekh Muhammad Yunus (murid Syekh Abdul Qadir al-Mandili di Masjidilharam) dan H. Mohammad (Muaz, 2012). Kemungkinan ia tamat tiga tahun kemudian, yakni pada tahun 1925. Pada tahun 1927, ia membuka sebuah madrasah di Medan. Ia sempat pergi ke Malaya tetapi sudah kembali ke Medan pada tahun 1928 dan mulai mengajar di MIT serta mendirikan Debating Club yang merupakan kelompok diskusi. Ia tetap terus melanjutkan studinya dimana ia belajar di Madrasah Hasaniyah yang dipimpin oleh Syekh Hasan Maksum (Sulaiman (ed.), 1956; Ja'far, 2015c).

Meski tidak lama, Abdurrahman Sjihab sempat belajar agama di Makkah sebagaimana tokoh Al Washliyah lainnya seperti Ismail Banda, Baharuddin Ali, Adnan Lubis, M. Husein Abd. Karim dan Hamdan Abbas. Ia belajar di sana hanya beberapa bulan sewaktu menunaikan ibadah haji, di mana ia menyempatkan untuk mendalami kajian keislaman kepada Syekh 'Ali al-Maliki, Syekh 'Umar Hamdan, Syekh Hasan Masysyath, Syekh Amin al-Kutubi dan Syekh M. 'Alawi (Sulaiman (ed.), 1956; Jamil, 1992; Mhd. Syahnan et al., 2019). Bahrum Jamil (1976) mengungkap bahwa Abdurrahman Sjihab pernah mengunjungi Madrasah Shaulatiyah yang dipimpin Syekh Rahmatullah al-Hindi dan Madrasah Dar al'Ulum yang dipimpin oleh Syekh Muhammad Yasin Padang. Tidak jelas apakah Sjihab berguru kepada kedua ulama terkenal tersebut. Yang jelas, Abdurrahman Sjihab mendapatkan limpahan ilmu dari ulama terkenal di Sumatera Timur seperti Syekh Muhammad Yunus dan Syekh Hasan Maksum; dan juga ulamaulama terkenal di Masjidilharam, Makkah. Tempat belajar Abdurrahman Sjihab 
merupakan lembaga pendidikan yang berasaskan mazhab Sunni (Syâfi'iyah dan Asy'ariyah), dan tentu saja ia merupakan penerus tradisi Sunni di Nusantara sebagaimana diakui oleh Syekh Siradjuddin Abbas dalam dua karyanya (2010; 2011). Itulah sebabnya, ideologi Sunni menjadi dasar dan penuntun dalam derap langkah perjuangannya dan gagasan yang diajukannya.

Menurut Hj. Fatimah Zahara (wawancara, 7 Maret 2018; 8 April 2020), Abdurrahman Sjihab menikah dengan Hj. Faridah. Mereka memperoleh sepuluh orang anak di antaranya Suhaimi Rangkuti, Fatimah Zahara Rangkuti, Ahmad Hadi Rangkuti, Aisyah Rangkuti, Faizah Rangkuti, Zuhdi Rangkuti, Nadrah Rangkuti dan Taufik Rangkuti. Tetapi, Hj. Faridah (merupakan anggota Pucuk Pimpinan Puteri Al Washliyah) meninggal dunia pada tanggal 8 Maret 1944 di Medan (Sulaiman (ed.), 1956). Hj. Faridah meninggal dunia saat melahirkan dan meninggalkan anak-anak yang masih kecil-kecil. Atas nasihat koleganya, terutama M. Arsjad Thalib Lubis, Abdurrahman Sjihab kembali menikah dengan Zubaidah Tamin dan dikaruniai lima orang anak yang di antaranya bernama Zakiyah Husnah, Sukainah Rusydah dan Asmawita. Zubaidah Tamin, istri dari Abdurrahman Sjihab, pernah menjadi Ketua Umum PP Puteri Al Washliyah dan berprofesi sebagai guru agama di Madrasah Ibtidaiyah Al Washliyah dan Pendidikan Guru Agama (PGA) Al Washliyah. Saat ini tidak ada anak-anak Abdurrahman Sjihab yang berkiprah dalam organisasi Al Washliyah kecuali Fatimah Zahara yang sempat menjadi pengurus Al Washliyah di DKI Jakarta.

Unik memang bahwa tidak banyak keturunan para pendiri Al Washliyah yang berkiprah dalam organisasi Islam terbesar di Sumatera Utara ini. Saat ini, tidak ada anak Abdurrahman Sjihab yang menjadi pengurus Al Washliyah. Ismail Banda memiliki seorang anak perempuan yang bernama Nurlela Isbanda, tetapi puterinya ini tidak memiliki keturunan lantaran ia tidak menikah sampai akhir hidupnya. Mungkin hanya anak dan cucu M. Arsjad Thalib Lubis yang masih berkiprah dalam organisasi Al Washliyah. Tidak pasti apakah anak dan cucu Yusuf Ahmad Lubis turut mendedikasikan potensi mereka dalam organisasi yang juga diinisiasi oleh orang tuanya tersebut mengingat tidak ada informasi akurat mengenai mereka. Karena itulah, sudah menjadi tugas pengurus Al Washliyah terkini untuk melibatkan kembali anak keturunan pendiri Al Washliyah 
sebagai bentuk apresiasi atas jasa-jasa orang tua mereka yang telah melahirkan Al Jam'iyatul Washliyah.

Usia Abdurrahman Sjihab memang tidak panjang, tetapi ia telah melakukan banyak hal bagi kemajuan agama dan negara. Ia hanya dikaruniai usia 45 tahun. Ia meninggal dunia di Medan, Senin, 7 Februari 1955 pukul 06.00 WIB. Lebih kurang 1,5 bulan ia dirawat di rumah sakit akibat sakit yang dideritanya sejak akhir tahun 1954. Karena terus menerus bekerja siang dan malam tanpa istirahat cukup, akhirnya ia terserang penyakit dalam. Ia dirawat beberapa hari di rumah sakit, dan setelah merasa sembuh ia kembali ke Jakarta untuk mengemban amanah sebagai anggota Dewan Perwakilan Rakyat Sementara (DPRS). Melihat ia kembali bekerja, beberapa kolega di Parlemen menasihati agar ia jangan bekerja dan beristirahat dahulu. Karena itu, pada bulan Desember 1954, ia kembali ke Medan dan beristirahat di rumah sakit. Selama berobat, ia hanya bisa meminum air susu dan obat-obatan. Karena tak kunjung sembuh, akhirnya ia menghembuskan nafas terakhirnya dalam usia kurang lebih 45 tahun (Sulaiman (ed.), 1956). Ia wafat ketika mengemban amanah sebagai Ketua Umum Pengurus Besar (PB) Al Jam'iyatul Washliyah, pengurus Pimpinan Pusat Partai Masjumi, dan anggota DPRS. Mohd. Natsir (1955), dalam majalah Hikmah, menyampaikan kabar duka ini dengan mengatakan “... ia sudah meninggalkan kita, al-Ustaz Abdurrahman Sjihab, justru pada saat kita yang ditinggal memerlukannya. Memerlukan buah tarjihnya yang jernih, pandangannya yang tajam, buah budinya yang halus..." Ia dimakamkan di halaman Masjid Jami' Silalas Sei Deli, sekitar lima meter dari makam Syekh Muhammad Yunus. Sampai saat ini, makamnya masih tetap diziarahi oleh para pengurus Al Washliyah, terutama saat perayaan ulang tahun Al Jam'iyatul Washliyah yang diperingati setiap tanggal 30 Nopember.

\section{Gerakan Sosial Religius}

Buku yang berjudul Kami Perkenalkan (1954) yang diterbitkan oleh Departemen Penerangan Republik Indonesia mengungkap biodata ringkas Abdurrahman Sjihab sebagai anggota Dewan Perwakilan Rakyat Sementara dimana terlihat bahwa Abdurrahman Sjihab memberikan perhatian terhadap pelestarian agama Islam terutama dalam bidang pendidikan sebagai fokus utama di awal karirnya 
sebagai pemuka agama di Sumatera Timur. Ia sendiri masuk dalam jajaran ulama terkemuka, khususnya di Provinsi Sumatera Utara. Ini terbukti dari biodatanya yang masuk dalam buku Sejarah Ulama-UlamaTerkemuka di Sumatera Utara yang diterbitkan Majelis Ulama Indonesia Propinsi Sumatera Utara. K.H. Siradjuddin Abbas, seorang ulama terkemuka dari organisasi Persatuan Tarbiyah Islamiyah, disingkat Perti (Koto, 2016) dalam bukunya Thabaqatus Syâfi iyah: Ulama Syâfi'i dan Kitab-kitabnya Dari Abad ke Abad memberikan penjelasan tentang Abdurrahman Sjihab sebanyak satu halaman. Abbas (2011) menyatakan bahwa Abdurrahman Sjihab sebagai sahabat karibnya adalah seorang ulama besar dari Medan, Provinsi Sumatera Utara dan berjasa bagi pengembangan ajaran dan dakwah Islam. Dalam buku Sejarah Ë Keagungan Madzhab Syâfi ${ }^{i}$, K.H, Siradjuddin Abbas (2010) memuji Abdurrahman Sjihab yang merupakan murid Syekh Hasan Maksum (mufti dalam mazhab Syâfi'i di Kerajaan Deli). Abbas juga menyematkan gelar syekh kepada Abdurrahman Sjihab dan menyebutnya “tiang tengah” mazhab Syâfi'i di Provinsi Sumatera Utara. Yang ingin dipertegas adalah bahwa Abdurrahman Sjihab adalah seorang ulama yang menganut mazhab Sunni, dalam fikih menganut mazhab Syâfi'i dan dalam bidang akidah menganut mazhab Ahlussunnahwaljamaah. Ideologi Sunni inilah yang kelak menjadi dasar dan penuntun perjuangannya upaya memajukan agama, bangsa dan negara.

Dalam memperkukuh tradisi Sunni di tanah kelahirannya, Sumatera Timur, Abdurrahman Sjihab menyadari bahwa agama Islam tidak bisa dilestarikan jika dilakukan secara perorangan, melainkan harus terorganisir melalui wadah organisasi dan menghimpun seluruh potensi umat untuk menegakkan agama Islam. Itulah sebabnya, ketika telah menyelesaikan pendidikannya dalam bidang keagamaan, ia bersama koleganya mendirikan Debating Club. Dalam perkumpulan pelajar MIT ini, Abdurrahman Sjihab menjadi Ketua. Pengurus lainnya adalah Sjamsuddin, Ismail Banda, Adnan Nur dan Sulaiman. Melalui Debating Club, mereka "membahas persoalan-persoalan agama Islam dan masyarakat" (Sulaiman (ed.), 1956). Usia perkumpulan ini tidak kurang hanya dua tahun saja.

Tidak puas dengan Debating Club, Abdurrahman Sjihab bersama kolega berupaya mengkonversi Debating Club hanya dari sekadar kelompok diskusi menjadi sebuah organisasi yang bertujuan untuk "memajukan, mementingkan 
dan menambah tersiarnya agama Islam" (Sjamsuddin, 1956). Oleh Syekh Muhammad Yunus (Direktur Maktab Islamiyah Tapanuli), organisasi tersebut pada tahun 1930 diberi nama dengan Al Jam'iyatul Washliyah, yang menurut Bahrum Jamil (1976) berarti "perhimpunan Islam yang saling menghubungkan silaturahmi, perhimpunan yang mempertalikan kasih dan sayang penuh persaudaraan yang mesra sekalian kaum muslimin." Organisasi yang didirikan bersama para koleganya ini berasas Islam. Dari aspek mazhab, Al Washliyah menganut fikih Syâfi' iyah dan teologi Asy'ariyah (Ja'far: 2016a dan 2019a). Para pengurus dan anggota Debating Clubyang terlibat dalam usaha mendirikan Al Washliyah adalah Abdurrahman Sjihab, Yusuf Ahmad Lubis, Adnan Nur, M. Isa, Ismail Banda, A. Wahab, M. Arsjad Thalib Lubis, dan Sjamsuddin (Sulaiman (ed.), 1956). Mereka menginisiasi dan menghadiri serangkaian rapat pembentukan organisasi yang bernama Al Jam'iyatul Washliyah sampai akhirnya diresmikan di Medan, 30 Nopember 1930, bertepatan dengan tanggal 9 Rajab 1349 hijriah. Karena itu, kedelapan tokoh ini layak disebut sebagai pendiri Al Jam'iyatul Washliyah.

Dilihat dari capaian organisasi, Al Washliyah di bawah komando Abdurrahman Sjihab memberikan perhatian intens terhadap bidang pendidikan, dakwah dan amal sosial. Tetapi, ini bukan berarti organisasi Islam asal Sumatera Timur ini abai terhadap persoalan politik (Ja'far: 2019b). Khusus di bidang pendidikan, menurut pengakuan Mahmud Yunus (1993), Al Washliyah sampai tahun 1955, saat Abdurrahman Sjihab baru saja meninggal dunia, mengelola 523 unit madrasah dan 48 unit sekolah, sedangkan kitab kuning dari tradisi Sunni menjadi bacaan para pelajar (Ja'far, 2017) yang pada era ini berjumlah lebih kurang 70.000 pelajar putra dan putri. Capaian ini tidak bisa lepas dari sosok Abdurrahman Sjihab yang menjadi pemimpin Al Washliyah dalam rentang waktu yang panjang. Bahrum Jamil (1976) memberikan sebuah testimoni pamungkas dengan mengatakan "kalau alm. Abdurrahman Sjihab sering sukses dan cemerlang di dalam kepemimpinannya, maka hal itu mungkinlah karena beliau begitu cinta membaca al-Qur'an” (h. 11).

Meskipun Al Washliyah sempat sulit berkinerja selama dua tahun pertama (Pengoeroes Besar Djam ijatoel Washlijah, 1936), tetapi kemudian organisasi ini relatif sukses dalam mengelola dan mengembangkan pendidikan, dan ini tidak terlepas dari perhatian intens Abdurrahman Sjihab sebagai Ketua Umum 
Ulama Mandailing Awal Abad ke-20: ... (Ja'far)

Pengurus Besar (PB) Al Washliyah. Perhatian ini terlihat dari jabatan yang diemban dalam organisasi ini. Selain menjadi pimpinan tertinggi, ia juga mengetuai Madjlis Tarbijah Umumi (bidang pendidikan) sekaligus Ketua Madjlis Penjiaran (bidang dakwah). Dalam majelis lain, ia bahkan menjadi anggota Madjlis Muballigh. Dengan demikian, selama menjadi Ketua PB Al Washliyah, ia tidak pernah duduk manis berpangku tangan dan jauh dari sifat ingin dilayani dan dihormati tanpa batas oleh bawahannya. Benar bahwa ia adalah pimpinan tertinggi Al Washliyah, tetapi ia tetap tekun bekerja demi kemajuan organisasi ini dengan memimpin langsung dua majelis yang bergerak dalam bidang pendidikan dan bidang dakwah, dan ia bahkan berkenan menjadi salah satu anggota dalam majelis lainnya. Ia pun turun tangan langsung dengan menjadi direktur dan guru di Madrasah al-Muallimin dan Madrasah al-Muallimat yang didirikan pada tanggal 7 Desember 1938 (Sulaiman (ed.), 1956). Terlihat bahwa Abdurrahman Sjihab adalah sosok pemimpin yang rendah hati dan pekerja keras. Menjadi pimpinan tertinggi tidak lantas membuatnya menjadi sosok yang arogan.

Abdurrahman Sjihab, sebelum terlibat dalam dunia politik lebih jauh pasca kemerdekaan, memberikan perhatian intens terhadap dunia pendidikan dan intelektual. Melalui Al Washliyah, ia menginisiasi pembangunan madrasah dan sekolah dan meningkatkan kualitas pendidikan dalam rangka mencerdaskan anak bangsa di tengah cengkraman kolonial Belanda guna menyiapkan landasan yang kukuh dalam merebut dan mempertahankan kemerdekaan. Sebagaimana dicatat oleh Mahmud Yunus (1993) terdahulu bahwa semasa kepemimpinan Abdurrahman Sjihab, Al Washliyah mengelola 523 unit madrasah dan 48 unit sekolah, dan lembaga pendidikan ini tersebar di tiga Keresidenan: Sumatera Timur, Aceh dan Riau, meskipun secara kuantitas lebih banyak berkembang di Sumatera Timur. Dalam organisasi Al Washliyah, ia merupakan inisiator pendirian Madrasah Al Jam' iyatul Washliyah yang pertama. Madrasah ini didirikan di Medan, 1 Agustus 1932, dua tahun setelah Al Washliyah diresmikan (Sulaiman (ed.), 1956).

Hal menarik lain adalah bahwa Sjihab menginisiasi pendirian madrasah yang dikhususkan untuk pelajar perempuan, sebuah keputusan yang tidak populer di masa itu. Ide ini digulirkan pada tanggal 4 Mei 1940 oleh Abdurrahman 
Sjihab yang didukung Udin Sjamsuddin dan pada awalnya kurang mendapatkan sambutan dari tokoh masyarakat. Ini mungkin karena sangat jarang didirikan madrasah khusus untuk pelajar perempuan sebelumnya. Dalam rangka pembangunan madrasah ini, keduanya mengundang 200 orang tokoh untuk membicarakan ide tersebut, dan jumlah orang yang hadir ternyata hanya 13 orang saja yang kemudian bersedia menjadi panitia pembangunan madrasah (Sulaiman (ed.), 1956). Akhirnya, Al Washliyah berhasil membangun sebuah madrasah yang dikhususkan untuk pelajar perempuan, yang dalam literatur disebut dengan Madrasah Puteri. Ini, sangat dimungkinkan, merupakan gagasan pembaruan Abdurrahman Sjihab dalam bidang pendidikan di mana ia hendak menegaskan kepada umat bahwa laki-laki dan perempuan memiliki kesamaan hak dalam bidang pendidikan.

Tidak saja memperhatikan kuantitas lembaga pendidikan, Abdurrahman Sjihab juga fokus terhadap peningkatan kualitas madrasah dan sekolah yang dikelola Al Washliyah. Untuk itu, ia banyak belajar dengan pengasuh lembaga pendidikan yang lebih dahulu maju dan modern. Dua contoh berikut menjadi bukti betapa ia memikirkan cara untuk memajukan lembaga pendidikan yang dibangun oleh Al Washliyah. Pertama, pada tahun 1939, sembilan tahun pasca Al Washliyah diresmikan, Abdurrahman Sjihab bersama Nukman Sulaiman dan Abdurrahim Sjihab menghadiri Kongres Persatuan Tarbiyah Islamiyah (Perti) ke-2 yang diadakan di Bukittinggi, 28 April-5 Mei 1939. Kesempatan ini digunakan Abdurrahman Sjihab, selain memenuhi undangan Pengurus Besar Perti, untuk meninjau lembaga-lembaga pendidikan di Sumatera Barat yang dikenal lebih maju dan modern, dan bertemu dengan ulama dan tokoh pendidikan di sana. Ia berdiskusi dengan Syekh Ibrahim Musa Parabek, A. Gaffar Jambek, Rahmah El Yunusiah, A. Hakim Hamid/Tuanku Mudo dan Mahmud Yunus (Sulaiman (ed.), 1956).

Kedua, sewaktu menunaikan ibadah haji tahun 1939/1940, sebagaimana keterangan Bahrum Jamil (1985), Abdurrahman Sjihab mempelajari sistem pendidikan yang diterapkan di lembaga pendidikan yang ada di Saudi Arabia. Ia berkunjung ke Madrasah Shaulatiyah yang dipimpin Syekh Rahmatullah al-Hindy dan Madrasah Dar al-'Ulum yang dipimpin Syekh Muhammad Yasin 
Padang. Dari kunjungan ini, ia mengenal kedua ulama tersebut dan beberapa ulama lain seperti Syekh Zakariya' Abdullah Billah, Syekh Mukhtar Palembang dan Syekh Mukhtar Banten. Studi banding Abdurrahman Sjihab memberikan keuntungan ganda kepadanya: mendapatkan pengetahuan tentang sistem pendidikan madrasah yang lebih maju dan modern; dan mengenal profil dan pemikiran para ulama yang lebih dahulu sukses dalam mengembangkan dan memajukan lembaga pendidikan yang mereka bangun.

Perhatian Abdurrahman Sjihab terhadap dunia intelektual tidak kalah dari perhatiannya terhadap pengembangan dunia pendidikan. Tercatat bahwa ia menghasilkan beberapa buku dan sejumlah artikel. Buku pertama berjudul Penoentoen Hadji: Tjara Mengerdjakan Hadji dengan Praktis yang diterbitkan Boekhandel Islamijah di Medan tahun 1940. Buku ini, kata Sjihab (1940) dalam ejaan lama, "mengandoeng hoekoem2 hadji dan oemrah moelai dari mengerdjakannja hingga selesai. Soesoenannja sengadja saja pilihlah dengan jang semoedahmoedahnja dapat dipahami dan diartikan" (h. 4). Buku ini terdiri atas 54 halaman.

Buku kedua berjudul Mengoendjoengi Tanah Haram yang juga diterbitkan Boekhandel Islamijah di Medan. Sampai saat ini, buku ini belum ditemukan, sehingga tidak diketahui tahun terbit buku ini. Tetapi, info buku kedua ini terdapat dalam halaman belakang dari buku Penoentoen Hadji. Isi buku ini, kata Sjihab (1940) dalam ejaan lama, "meriwajatkan pengalaman dan pemandangan saja, moelai dari saja meninggalkan tanah air Indonesia (24 Agustus 1939) sampai kembalinja (16 Februari 1940).” Buku ini terdiri atas lebih dari 400 halaman. Dengan demikian, buku ini bisa dikatakan sebagai buku catatan perjalanan "legal-spiritual" Sjihab selama menunaikan ibadah haji.

Buku Peringatan Al Djamijatul Washlijah 1/4 Abad (1956) menginformasikan dua karya lain, yakni Pidato Agama di Radio dan Biografie H. Abd. Rahman Sjihab. Hanya, belum ditemukan informasi tentang keberadaan buku Pidato Agama di Radio. Bahrum Jamil (1992) menginformasikan bahwa buku Pidato Agama (Islam) di Radio merupakan kumpulan pidato yang disampaikan penulisnya di Radio Republik Indonesia (RRI) dan buku ini belum dicetak/diterbitkan. Kemudian, diketahui bahwa autobiografi Abdurrahman Sjihab terdiri atas 5 jilid dengan total halaman sebanyak 2500 halaman. Sayang sekali, draft autobiografi ini 
Islamijah: Journal of Islamic Social Sciences, Volume 1, Number 1, January 2020: 1-25

belum ditemukan sampai saat ini. Siradjuddin Abbas (2011) menyatakan bahwa Abdurrahman Sjihab membuat catatan riwayat hidupnya, tetapi catatan tersebut belum dicetak untuk bisa dibaca oleh umat terkait perjuangannya untuk memajukan agama dan negara. Pikiran-pikiran Abdurrahman Sjihab juga agaknya masih "asing" di kalangan kader Al Washliyah mengingat belum ada peneliti yang mengkaji pemikirannya.

Dua buku Abdurrahman Sjihab yang pertama diterbitkan oleh penerbit Islamiyah di Medan. Penerbit Islamiyah, menurut Abdul Halim Hasan (2011), didirikan oleh Bagindo Siregar dan menerbitkan buku-buku agama Islam. Banyak ulama menerbitkan karangan mereka di penerbit yang sebelum kemerdekaan bernama Boekhandel Islamijah ini, misalnya Hamka, T.M. Hasbie Ash Shiddieqy, Adnan Lubis, M. Arsjad Thalib Lubis, Udin Sjamsuddin (1941), Abdul Halim Hasan (1936; 1960), Zainal Arifin Abbas (1948), Abdul Rahim Haitami, Ahmad (1956), M. Nuh Hudawi (1969), Abubakar Ya'cub (1975) dan Nukman Sulaiman (1968). Penerbit Islamiyah merupakan penerbit buku-buku Islam ternama di Indonesia kala itu. Kota Medan di Keresidenan Sumatera Timur memang pernah dikenal sebagai pusat penerbitan buku-buku dan banyak penerbit berdiri dan memberikan sumbangsih bagi kemajuan intelektual di Nusantara seperti Saiful, Al-Ichwan, Madju dan Rimbow.

Beberapa tulisan Abdurrahman Sjihab dalam bentuk artikel terbit dalam buku yang diterbitkan Pengurus Besar Al Washliyah dan majalah Medan Islam. Salah satu artikel yang ditemukan berjudul "Memperingati Al Djam'ijatul Washlijah 21 Tahun 30 November 1930-30 November 1951" setebal 19 halaman dan diterbitkan dalam buku 21 Tahun Al Dj. Washlijah (1951). Dalam buku yang sama, terdapat sebuah tulisannya yang berjudul "Pandangan Terhadap Kementerian Agama.” Dalam majalah Medan Islam, Sjihab menyumbang beberapa tulisan, di antaranya "Hari Peringatan Ulang Tahun Ke XX Al Djamijatul Washlijah 30 Nopember 1930-30 Nopember 1950," "Pangkal Kemenangan," "Menjamboet Hari Raja” dan "Tarich Imam Aboehanifah.”

Hampir seluruh pendiri dan ulama Al Washliyah menulis dalam bidang hukum Islam. Tetapi, mereka memiliki keunikan masing-masing. Abdurrahman Sjihab juga menulis sejarah. Dua pendiri Al Washliyah lainnya, M. Arsjad Thalib 
Lubis (1983) dan Yusuf Ahmad Lubis (1973; Ja'far, 2020) menulis dalam bidang kristologi. Adnan Lubis (1954; 1962; 1967)-bukan Adnan Nur Lubis yang merupakan pendiri Al Washliyah, politisi PNI, dan pernah menjabat sebagai Ketua DPRD Propinsi Sumatera Utara-cenderung menulis dalam bidang tafsir, filsafat, tasawuf dan sejarah. Ismail Banda menulis dalam bidang filsafat dan kajian Islam secara umum. Dari segi judul, tentu saja karangan Abdurrahman Sjihab tidak sebanyak karya M. Arsjad Thalib Lubis atau Yusuf Ahmad Lubis yang telah menulis puluhan buku dengan ragam topik. Tetapi, Abdurrahman Sjihab memiliki keunggulan yang tidak ditemukan dalam diri pendiri Al Washliyah lainnya, yaitu ia menulis autobiografi setebal 2.500 halaman. Tidak ada ulama di lingkungan Al Washliyah yang menulis autobiografi secara tuntas.

Abdurrahman Sjihab, selain mengarang, juga mengelola majalah. Tercatat bahwa ia pernah menjadi anggota pimpinan redaksi Medan Islam dan pimpinan Raudatul Muta'allimin. Medan Islam terbit pertama kali pada 1 Nopember 1933 dan awalnya di bawah pimpinan Abd. Wahab dan Yusuf Ahmad Lubis, sedangkan Raudatul Muta'allimin terbit pertama sekali pada bulan Februari 1937. Di lingkungan Al Washliyah sebelum kemerdekaan, dikenal beberapa majalah lain seperti Suara Al Jam'iyatul Washliyah yang terbit mulai 1 Maret 1939, Dewan Islam yang dikelola M. Arsjad Thalib Lubis sejak 1935, majalah Kerdja yang dikelola Gerakan Pemuda Al Washliyah, atau majalah Bulan Bintang. Sayang sekali, sebagian besar majalah tersebut tidak terkoleksi secara baik oleh para pengurus Al Washliyah di level manapun.

Selain memajukan Islam dan kaum Muslim melalui jalur pendidikan dan intelektual, Abdurrahman Sjihab membentengi akidah umat dari aliran Ahmadiyah. Merespons kehadiran kelompok Ahmadiyah di Sumatera Timur, Abdurrahman Sjihab bersama kolega mendirikan Komite Pemberantas I'tikad Ahmadiyah al-Qadiyany pada tanggal 10 Nopember 1935. Abdurrahman Sjihab dipercaya sebagai Ketua, sedangkan M. Arsjad Thalib Lubis ditunjuk sebagai Sekretaris. Beberapa pengurus komite ini adalah Mhd. Hanafy, Abd. Majid, Abdurrahman Onderwijzer, Abdul Malik, Ahmad Marzuki, Abdullah, Ismail, Mangaraja Ihutan, Djalaluddin dan M.A. Dasuki. Komite ini mendiskusikan masalah tentang kedudukan Mirza Ghulam Ahmad dan para pengikutnya. 
Islamijah: Journal of Islamic Social Sciences, Volume 1, Number 1, January 2020: 1-25

Untuk mendapatkan kepastian hukum, mereka mengajukan pertanyaan kepada 53 ulama di Sumatera Timur (di antaranya Syekh Hasan Maksum dan Syekh Muhammad Yunus) terkait pendiri dan pengikut aliran Ahmadiyah, dan kesimpulannya adalah bahwa "Mirza Ghulam Ahmad al-Qadiyany kafir (murtad), pengikutpengikutnya juga kafir (murtad), berlindunglah kita dari keadaan ini” (Majelis Ulama Sumatera Utara, 1982). Tengkoe Fachroeddin bahkan mendebat tokoh Ahmadiyah terkait ajaran yang diutarakan oleh Mirza Ghulam Ahmad dan hasil debat mereka dicatat dan diterbitkan oleh Mangaradja Ihoetan dan Mahmoed Ismail Loebis (1934). Upaya Abdurrahman Sjihab terus dilanjutkan oleh ulamaulama Al Washliyah kontemporer, misalnya oleh Ustaz Ramli Abdul Wahid yang menulis buku yang berjudul Kupas Tuntas Ajaran Ahmadiyah (2011).

\section{Gerakan Sosial Politik}

Tentu saja, Abdurrahman Sjihab anti terhadap kolonialisme Belanda dan penjajahan Jepang. Keterpurukan kaum Muslim di era ini akhirnya membentuk sikap kritis Sjihab, dan kondisi inilah yang menyebabkan lambat laun ia mulai bersentuhan dengan dunia politik. Kemerdekaan bangsa Indonesia adalah sebuah keniscayaan, dan ia memperjuangkan kemerdekaan ini melalui wadah Al Jam'iyatul Washliyah. Sebagai pimpinan tertinggi organisasi, ia membangun relasi dan koordinasi dengan organisasi-organisasi Islam lainnya demi kemerdekaan Indonesia dan kaum Muslim kembali mulia.

Persentuhan Abdurrahman Sjihab dengan dunia politik selanjutnya terjadi ketika ia menghadiri Kongres ke-III Majelis Islam A'la Indonesia (MIAI) di Solo pada tanggal 7-8 Juli 1941. Sebelumnya, pada tanggal 9-15 Januari 1941, Al Washliyah mengadakan kongres ketiga di Medan. Beberapa peserta kongres mengusulkan agar Al Washliyah menjadi anggota MIAI tetapi kongres mengusulkan "menyokong MIAI di mana masa yang perlu tetapi tidak sebagai anggota." Artinya, Al Washliyah mendukung MIAI tetapi belum ingin menjadi anggota MIAI. Dalam Kongres MIAI ke-III di Solo, Abdurrahman Sjihab mengikuti sidang-sidang pleno dan rapat-rapat khusus meskipun bukan menjadi anggota MIAI. Salah satu keputusan kongres berkaitan dengan masalah tata negara di 
Ulama Mandailing Awal Abad ke-20: ... (Ja'far)

mana MIAI menuntut Indonesia berparlemen yang berdasar Islam (Sulaiman (ed.), 1956). Noer (1980) menyebutkan bahwa Abdurrahman Sjihab dipercaya oleh para peserta kongres untuk menjadi Ketua Komisi yang mengurus masalah penyiaran Islam dengan tugas utama membentuk Central Zending Islam di Indonesia. Yang ingin ditegaskan adalah bahwa dalam kongres inilah Abdurrahman Sjihab mulai terlibat dalam membicarakan masalah negara.

Semasa perjalanan ke pulau Jawa, Abdurrahman Sjihab menemui dan berdiskusi dengan ulama-ulama dari berbagai organisasi Islam. Ia misalnya menemui K.H. Abdul Wahid Hasyim dan K.H. Abdul Wahab dari Nahdlatul Ulama, Abikusno Tjokrosujoso dan Sjahbuddin Latif dari Partai Syarikat Islam Indonesia (PSII) dan Mohd. Natsir yang saat itu masih menjabat sebagai Direktur Pendidikan Islam Bandung. Pertemuan ini, tentu saja, menambah relasi dan keakraban Abdurrahman Sjihab dengan tokoh-tokoh nasional dan memperluas wawasannya tentang perkembangan politik di Indonesia.

Setelah bangsa Indonesia meraih kemerdekaan, Abdurrahman Sjihab atas nama PB Al Washliyah mendukung dan mempertahankan kemerdekaan Republik Indonesia. Setelah berita kemerdekaan sampai secara akurat ke tokohtokoh Sumatera Timur pada tanggal 9 Oktober 1945, Abdurrahman Sjihab atas nama PB Al Washliyah langsung mengirimkan pesan kepada Presiden Soekarno di Jakarta yang tertulis "Al Jam'iyatul Washliyah turut mempertahankan Republik Indonesia." Ia kemudian menginisiasi rapat khusus di Medan pada tanggal 27-28 Oktober 1945 dengan mengundang seluruh pengurus Al Washliyah mulai dari level Pengurus Besar sampai Pengurus Cabang dan Pengurus Ranting, serta pengurus organisasi bagian Al Washliyah untuk membicarakan masalah mempertahankan kemerdekaan. Rapat ini akhirnya menghasilkan keputusan yang ditujukan kepada Presiden Republik Indonesia, Gubernur Sumatera Utara, para pimpinan, guru, dan pemuda Al Washliyah. Keputusan yang ditujukan kepada Presiden Republik Indonesia adalah “...di atas nama 50.000 keluarga Al Jam' iyatul Washliyah menghendaki kemerdekaan 100\%..." Keputusan strategis ini ditandatangani oleh Abdurrahman Sjihab sebagai Ketua Umum PB Al Washliyah dan Udin Sjamsuddin sebagai Sekretaris PB Al Washliyah. Keputusan rapat ini dibahas lebih mendalam pada Kongres ke-V Al Jam'iyatul Washliyah 
Islamijah: Journal of Islamic Social Sciences, Volume 1, Number 1, January 2020: 1-25

di Pematangsiantar, 30 Nopember-2 Desember 1945 dimana kongres ini hanya dikhususkan untuk membicarakan soal mempertahankan kemerdekaan Republik Indonesia. Sjihab mendorong Madjlis Al Fatwa Al Washliyah-sekarang bernama Dewan Fatwa Al Jam'iyatul Washliyah (Ja'far, 2016b)-untuk mengeluarkan fatwa yang akhirnya diputuskan: "Wadjib atas tiap2 ummat Islam di Indonesia menolak kedatangan orang2 Belanda dan pembantu2nja jang hendak berkuasa di Indonesia. Orang Islam jang mati dalam pertempuran menolak orang Belanda dan pembantu2nja itu, dan matinja disebabkan pertempuran tersebut dengan nijat menegakkan agama Islam dihukumkan sjahid fi sabilillah.” Ini menunjukkan bahwa sebagaimana Nahdlatul Ulama di Jawa Timur, Al Washliyah di bawah kepemimpinan Abdurrahman Sjihab juga mengeluarkan resolusi jihad untuk mempertahankan kemerdekaan Indonesia. Fatwa strategis ini memang relatif jarang viralkan oleh para pengurus Al Washliyah dewasa ini.

Untuk mempertahankan kemerdekaan, Abdurrahman Sjihab membangun relasi dan komunikasi dengan para tokoh Muslim. Sekadar contoh, ia atas nama PB Al Washliyah menjadi anggota Pengurus Besar Majlis Islam Tinggi (MIT) Sumatera pada tahun 1945/1946. Di saat yang sama, ia juga menjadi Ketua Pimpinan Daerah MIT Sumatera Timur (Sulaiman (ed.), 1956). Beberapa bulan kemudian, ia menghadiri Kongres Islam Sumatera yang diadakan di Bukittinggi, 6-9 Desember 1945. Kegiatan ini dihadiri oleh ulama dari Aceh, Sumatera Timur, Tapanuli, Riau dan Sumatera Barat, di antaranya Syekh Ismail Abdul Wahab (Asahan), Syekh Sulaiman Arrasuli (Sumatera Barat), Syekh Dja'far Abd. Wahab (Tapanuli), dan Tengku Abdul Wahab (Aceh). Beberapa peserta kongres menyampaikan pidato yakni Gaffar Djambek, Tengku Sulaiman Mahmud, Syekh Ismail Abdul Wahab, Tengku Usman Husin, Umar Usman, Simaradjo, Mahmud Yunus, Dahlan Djambek, Darwis Ma'ruf dan Syekh Muhammad Djamil Djambek. Dua keputusan terpenting Kongres Islam Sumatra adalah "berjuang mengusir musuh dari tanah air kita ini atau menghancurkannya adalah hukumnya fardhu 'ain (bukan fardhu kifayah)," dan "Majlis Islam Tinggi Sumatra menjadi partai politik Islam"(Sulaiman (ed.), 1956). Dalam kongres ini, selain dipilih menjadi Ketua Panitera Haji (Toer, et al., 1999a), Abdurrahman Sjihab mendukung MIT menjadi partai politik. 
Ulama Mandailing Awal Abad ke-20: ... (Ja'far)

Dalam fase ini, Abdurrahman Sjihab sudah mulai menjadi seorang politisi. Tetapi, MIT tidak lama menjadi partai politik setelah sebuah partai politik Islam di tingkat nasional telah didirikan dengan nama Partai Masjumi. Pada tanggal 7 Maret 1946, pengurus MIT Sumatera Timur mendeklarasikan organisasi ini sebagai cabang Masjumi di Sumatera Timur. Menurut Anthony Reid (2014:252), Abdurrahman Sjihab menjadi Ketua Masjumi yang pertama di Sumatera Timur. Posisi ketua Masjumi kemudian digantikan oleh M. Yunan Nasution (Muhammadiyah) dan Bachtiar Joenoes (Muhammadiyah/Sabilillah). Kehadiran Masjumi di Medan tidak bisa dilepaskan dari posisi Abdurrahman Sjihab sebagai Ketua MIT Sumatera Timur. Karena MIT Sumatera Timur melebur dalam Masjumi, Abdurrahman Sjihab sebagai Ketua MIT secara otomatis menjadi Ketua Masjumi cabang Sumatera Timur. Sampai wafat tahun 1955, ia mendedikasikan dirinya menjadi pengurus Masjumi di level lokal dan nasional.

Abdurrahman Sjihab mendapatkan kepercayaan untuk menduduki sejumlah jabatan di level lokal. Ia menjadi pegawai Kantor Agama (1944-1945), Ketua Badan Keagamaan Republik Indonesia (1945), Wakil Kepala Dewan Agama dan Ketua Pejabat Agama Keresidenan Sumatera Timur Bahagian Agama Islam (1946). Ia kemudian dipercaya untuk menjabat sebagai Wakil Kepala Djawatan Agama Sumatera Utara di Kutaraja (1949) dan Inspektur Jabatan Sosial Sumatera Utara. Pada saat yang sama, ia merupakan anggota DPR Sumatera Utara dan anggota eksekutif DPR Sumatera Timur (1945-1948) (Sulaiman (ed.), 1956). Tampak bahwa Abdurrahman Sjihab merupakan pemuka agama yang dipercaya menduduki banyak jabatan, baik di bidang eksekutif (bidang agama) maupun di bidang legislatif. Dalam rentang waktu antara tahun 1944 sampai tahun 1947, ia telah menjadi pejabat publik di Keresidenan Sumatera Timur dan Propinsi Sumatera Utara dengan sejumlah posisi strategis. Ragam jabatan ini menjadi pengalaman penting bagi Sjihab ketika kelak ia menjadi anggota Komite Nasional Indonesia Pusat (KNIP) dan Dewan Perwakilan Rakyat Sementara (DPRS).

Enam fakta historis berikut juga menunjukkan bahwa Abdurrahman Sjihab turut aktif mempertahankan kemerdekaan Republik Indonesia. Pertama, Abdurrahman Sjihab bersama anggota PB Al Washliyah membentuk Madjelis 
Pertahanan Kemerdekaan Indonesia. Kedua, setelah terjadi Revolusi Sosial di Sumatera Timur, ia menjadi anggota Dewan Pemerintahan yang bertugas melaksanakan tugas-tugas pemerintahan. Dewan Pemerintahan ini terdiri atas lima orang yakni Gindo Siregar, A. Mutalib Moro, M. Junus Nasution, Abdurrahman Sjihab, dan M. Saleh Umar (Toer, et al., 1999b). Ketiga, saat terjadi agresi militer pertama, 21 Juli 1947, ia harus berpindah-pindah tempat bahkan hampir tertembak senjata tentara Belanda. Pada masa ini, ia sudah diangkat sebagai anggota KNIP. Ia turut berjuang secara bergerilya mulai dari Tebingtinggi, Pematangsiantar, Tigabinanga (Karo), bahkan sampai ke Tapanuli Selatan. Keempat, Sewaktu muncul gerakan yang bertujuan untuk memisahkan Sumatera Timur dari Negara Kesatuan Republik Indonesia, Abdurrahman Sjihab menentang gerakan ini dan bergerak melalui wadah Al Washliyah untuk mengembalikan Keresidenan Sumatera Timur ke pangkuan NKRI. Dalam Kongres Al Washliyah ke-VII di Medan, 8-11 April 1950, Abdurrahman Sjihab menandatangani keputusan kongres yang isinya “...menuntut supaya Negara Sumatera Timur (NST) dibubarkan dan seluruh Sumatera Timur dikembalikan kepada Republik Indonesia.” Kelima, Abdurrahman Sjihab melibatkan diri dalam Kongres Rakyat Sumatera Timur yang diadakan untuk menentukan status daerah Sumatera Timur. Dalam kepanitiaan kongres ini, ia duduk sebagai Wakil Ketua II Staf Pimpinan Umum sekaligus Ketua Fraksi Agama Islam. Sebagai seorang tokoh yang pro dengan Republik Indonesia, tentu saja ia mendorong agar kongres ini menolak keberadaan NST. Keputusan kongres ini adalah "semua kekacau balauan dan segala kesepian beragama akan hilang, kesangsian akan menjadi yakin kembali, hasrat umat yang beragama akan tenteram, bila Negara Sumatera Timur dibubarkan dan dikembalikan kepada Negara Republik Indonesia.” Keenam, ia menjadi anggota Badan Penasihat Panitia Persiapan Negara Kesatuan Sumatera Timur (PPNKST) yang dilantik oleh Menteri Dalam Negeri pada tanggal 14 Juli 1950. Tujuan panitia ini adalah "mengatur persiapan pembubaran NST dan pemasukannya ke dalam Negara Kesatuan yang akan menggantikan Republik Indonesia Serikat (RIS)” (Sulaiman (ed.), 1956).

Tidak saja berkiprah secara lokal, Abdurrahman Sjihab turut mengisi kemerdekaan dengan menghabiskan waktu dan pikiran untuk berkiprah secara 
Ulama Mandailing Awal Abad ke-20: ... (Ja'far)

nasional. Pada tahun 1947, ia dipilih menjadi anggota Komite Nasional Indonesia Pusat (KNIP). Ini merupakan masa awal Sjihab berkiprah untuk bangsa dan negara di pentas nasional. Menurut Budiardjo (2015), KNIP adalah "badan pembantu Presiden yang pembentukannya didasarkan pada keputusan sidang Panitia Persiapan Kemerdekaan Indonesia (PPKI) tanggal 18 Agustus 1945” (h. 331). Anggota KNIP dilantik oleh Presiden Soekarno pada tanggal 29 Agustus 1945. Tugas KNIP kemudian berubah, yakni melaksanakan tugas legislatif. Jumlah anggota KNIP awalnya sebanyak 137 orang, kemudian bertambah menjadi 536 orang. Abdurrahman Sjihab dilantik sebagai anggota KNIP pada tahun 1947, dua tahun setelah badan ini dibentuk. Di KNIP, Sjihab semakin mengenal dan berinteraksi dengan berbagai tokoh nasional, di antaranya Kasman Singodimedjo, Adam Malik, Sutan Sjahrir dan Amir Sjarifuddin.

Tiga tahun kemudian, setelah tidak menjadi pimpinan Masjumi di Sumatera Timur, Abdurrahman Sjihab banyak menghabiskan waktu dan pikiran dengan menjadi pengurus DPP Masjumi. Sejak tahun 1949, Abdurrahman Sjihab menjadi salah satu anggota Dewan Pimpinan Pusat Masjumi (DPP) di Jakarta (Noer, 1987). Dalam Muktamar ke-V Masjumi di Jakarta, Abdurrahman Sjihab ditunjuk sebagai anggota Dewan Organisasi DPP Masjumi. Dua tokoh Al Washliyah lainnya ditunjuk sebagai anggota Dewan Partai DPP Masjumi, yaitu M. Arsjad Thalib Lubis dan Anas Tanjung. Dalam Muktamar Masjumi ke-VI pada tahun 1952 dimana Mohd. Natsir menjadi Ketua DPP Masjumi, Abdurrahman Sjihab ditunjuk sebagai Ketua Madjlis Sjuro DPP Masjumi. Di antara ulama yang menjadi pengurus harian Madjlis Sjuro DPP Masjumi periode ini ada A.R. Sutan Mansur, K.H. Sobry, H.M. Saleh Su'aidy, K.H. Taufiqurrahman, H. Iskandar Idris dan K.H. Ahmad Azhary. Tiga ulama terkenal dari Sumatera Utara juga menjadi anggota Madjlis Sjuro, yakni Syekh M. Arsjad Thalib Lubis, K.H. Salim Fachry dan Syekh Musthafa Husein (Departemen Penerangan, 1954). Sampai akhir hidupnya (1955), Abdurrahman Sjihab terus setia menjadi salah satu tokoh pendukung Masjumi.

Pada tahun 1954, Abdurrahman Sjihab ditunjuk sebagai anggota Dewan Perwakilan Rakyat Sementara (DPRS) dari Partai Masjumi dengan nomor anggota 185. Ia menggantikan posisi S. Prawoto Sudibjo sebagai anggota DPRS dan 
Islamijah: Journal of Islamic Social Sciences, Volume 1, Number 1, January 2020: 1-25

dilantik pada tanggal 24 Maret 1954. Pimpinan Fraksi Masjumi periode ini adalah Burhanuddin Harahap (Ketua), K.H. Tjikwan (Wakil Ketua I) dan Zainal Abidin Ahmad (Wakil Ketua II). Di DPRS, ia duduk sebagai anggota Seksi E yang mengurus masalah pendidikan, pengajaran dan kebudayaan, agama dan kesehatan. Di antara tokoh Masjumi di Seksi E ini adalah K.H. Ahmad Azhari, K.A. Djohar, Ki Bagus Hadikusumo, Hasan Basrie, Mohd. Machfud, Sunarjo Mangunpuspito dan Zainal Abidin Ahmad (Departemen Penerangan, 1954). Boleh dikatakan bahwa ia adalah tokoh Al Washliyah pertama yang duduk sebagai anggota parlemen meskipun ia hanya setahun menjabat sebagai anggota DPRS karena ia meninggal dunia pada tanggal 7 Februari 1955 di Medan. Kedudukannya sebagai anggota DPRS digantikan oleh H. Mohammad Dja'far Zainuddin (Sekretariat DPR-GR, 1983), sesuai rapat PB Al Washliyah pada tanggal 11 Maret 1955. H. Mohammad Dja'far Zainuddin adalah anggota perwakilan Al Washliyah di Jakarta. Di internal Al Washliyah, Udin Sjamsuddin ditunjuk sebagai Pemangku Ketua Umum PB Al Washliyah (Sulaiman (ed.), 1956). Selama menjadi politisi, Abdurrahman Sjihab mengenal banyak tokoh nasional seperti Mohd. Natsir, Wahid Hasyim dan Siradjuddin Abbas.

Sejauh ini belum ditemukan data tentang pemikiran politik Abdurrahman Sjihab. Ini berbeda dari dua rekannya dalam organisasi Al Washliyah, Adnan Lubis dan M. Arsjad Thalib Lubis, yang pernah menuliskan gagasan mereka dalam bidang politik. Sewaktu di Konstituante, Adnan Lubis menyampaikan pidatonya tentang negara Islam dan beberapa artikelnya dalam bidang politik telah diterbitkan dalam majalah al-Islam. Sedangkan M. Arsjad Thalib Lubis (1967) menulis tentang kedudukan kepala negara (Presiden Soekarno) dalam perspektif hukum Islam, ia bahkan menulis artikel khusus untuk merespons pemberian gelar waliyul amri dharuri oleh Nahdlatul Ulama kepada Presiden Soekarno. Mungkin saja Abdurrahman Sjihab juga memiliki gagasan dalam bidang politik mengingat beberapa karangannya masih belum ditemukan. 
Ulama Mandailing Awal Abad ke-20: ... (Ja'far)

\section{Penutup}

Ada sejumlah tokoh Masjumi dari Sumatera yang belum dituliskan biografi dan gerakan mereka dalam memajukan kaum Muslim dan negara Indonesia. Tulisan ini setidaknya berhasil menampilkan riwayat kehidupan seorang tokoh Masjumi yang berasal dari Medan, Sumatera Timur (kini Sumatera Utara) dan berafiliasi dengan Al Jam'iyatul Washliyah. Ia bernama Abdurrahman Sjihab, seorang ulama dari etnis Mandailing dan murid dari Syekh Hasan Maksum (ulama Melayu yang pernah berguru kepada Syekh Ahmad Khatib al-Minangkabawi). Sjihab merupakan ulama yang mewariskan tradisi Sunni dari ulama-ulama di Sumatera Timur maupun ulama-ulama Masjidilharam. Di era kolonial sampai awal kemerdekaan Indonesia, ia telah banyak bekerja dalam rangka memuliakan Islam, memajukan kehidupan kaum Muslim dan memperjuangkan kemerdekaan Indonesia. Dalam bidang sosial keagamaan, ia membangun Al Jam'iyatul Washliyah bersama teman-temannya. Organisasi Islam ini bergerak dalam bidang pendidikan, dakwah dan sosial. Ratusan madrasah dan puluhan sekolah berhasil dibangun atas nama Al Washliyah, bukan atas nama pribadinya. Baik laki-laki maupun perempuan diberikan hak yang sama dalam memperoleh pendidikan di bawah naungan Al Washliyah. Ia pun tidak abai terhadap masuknya paham Ahmadiyah diSumatera Timur. Dalam bidang sosial politik, Sjihab memperjuangkan kemerdekaan Indonesia, mengembalikan Sumatera Timur ke pangkuan Republik Indonesia dan memperjuangkan Islam dalam kehidupan bernegara melalui wadah Masjumi. Di akhir hidupnya, ia merupakan Ketua Majelis Syuro DPP Masjumi dan Ketua PB Al Jam'iyatul Washliyah. Meskipun tidak dikaruniai usia yang panjang (45 tahun), ia sudah ikut memperjuangkan berdirinya Republik Indonesia dan meletakkan pondasi yang kokoh bagi kelanjutan perjuangan kaum Muslim khususnya keluarga besar Al Washliyah di Sumatera Timur, Provinsi Sumatera Utara, atau bahkan Republik Indonesia. Perjuangannya tentu saja tanpa pamrih dan predikat pahlawan nasional tidak pernah diharapkannya, dan nyatanya memang sampai saat ini gelar itu tidak pernah disematkan kepadanya. 
Islamijah: Journal of Islamic Social Sciences, Volume 1, Number 1, January 2020: 1-25

\section{Pustaka Acuan}

Abbas, Siradjuddin. (2010). Sejarah $\mathfrak{E}$ keagungan madzhab Syâfi ii. Pustaka Tarbiyah Baru.

Abbas, Siradjuddin. (2011). Thabaqatus Syâfi'iyah: Ulama Syâfi'i dan kitab-kitabnya dari abad ke abad. Pustaka Tarbiyah Baru.

Abbas, Zainal Arifin. (1948). Tarich nabi Muhammad s.a.w. Islamijah.

Ahmad. (1956). Risalat ilmu tauhid. Islamyah.

Budiardjo, Miriam. (2015). Dasar-dasar ilmu politik. Gramedia.

Departemen Penerangan Republik Indonesia. (1954). Kami perkenalkan. Departemen Penerangan Republik Indonesia.

Departemen Penerangan Republik Indonesia. (1954). Kepartaian dan parlementaria Indonesia. Departemen Penerangan Republik Indonesia.

Hasan, Abdul Halim, et al. (1936). Tafsir al-quranul karim. Jilid 1-8. Islamyah.

Hasan, Abdul Halim, et al. (1960). Pemimpin puasa. Islamyah.

Hasan, Abdul Halim. (2011). Tafsir al-ahkam. Kencana.

Ihoetan, Mangaradja dan Mahmoed Ismail Loebis. (1934). Openbarr-debat oetoesan Ahmadijah Qadian contra Tengkoe Fachroeddin pada 15 dan 22 juli 1934 di Medan. t.p.

Ja'far. (2015a). Biografi ketua umum pengurus besar Al Jam'iyatul Washliyah 1930. 2015. Perdana Publishing.

Ja'far. (2015b). Tradisi intelektual Al Washliyah: Biografi ulama kharismatik dan tradisi keulamaan. Perdana Publishing.

Ja'far, Ja'far. (2015c). Tarekat dan gerakan sosial keagamaan Shaykh Hasan Maksum. Teosofi: Jurnal Tasawuf dan Pemikiran Islam, 5(2), 269-293. https:/ /doi.org/10.15642/teosofi.2015.5.2.269-293

Ja'far. (2020). Karya-karya H. Yusuf Ahmad Lubis dalam bidang kristologi. Dalam Dahlia Lubis dan Zuhri Arif (eds.), Peringatan 1 abad maktab islamiyah tapanuli. K-Media.

Ja'far, Ja'far. (2016a). Peran Al Jam'iyatul Washliyah dalam merevitalisasi madhhab Shafi'i di era kontemporer. Justicia Islamica, 13(1), 1-30. https://doi.org/ 10.21154/justicia.v13i1.451 
Ulama Mandailing Awal Abad ke-20: ... (Ja'far)

Ja'far, Ja'far. (2016b). Respons Dewan Fatwa Al Jam'iyatul Washliyah terhadap isu akidah dan syariah di era global. al-Manahij: Jurnal Kajian Hukum Islam, 10(1), 97-118. https://doi.org/10.24090/mnh.v10i1.919

Ja'far, Ja'far. (2017). Khazanah kitab kuning di madrasah Al Jam 'iyat Al Washliyah. Jurnal Pendidikan Agama Islam Al-Thariqah, 2(2), 124-134. https://doi.org/ 10.25299/althariqah.2017.vol2(2).1041

Ja'far, Ja'far. (2019a). Al Jam'iyatul Washliyah dan pelestarian akidah Ahl AlSunnah wa Al-Jama'ah di Indonesia. Islamica: Jurnal Studi Keislaman, 14(1), 54-81. https://doi.org/10.15642/islamica.2019.14.1.54-81

Ja'far, Ja'far. (2019b). Pemikiran politik islamisme moderat Al Jam'iyatul Washliyah. al-A'raf: Jurnal Pemikiran Islam dan Filsafat, 16(2), 191-222. https://doi.org/ 10.22515/ajpif.v16i2.1762

Jamil, Bahrum. (1976). Alwashliyah buah hati ummat Islam Indonesia kini sudah berusia 46 tahun. Majlis Tabligh dan Tazkir (Penerangan).

Jamil, Bahrum. (1985). Alwashliyah buah hati ummat Islam dan keputusan muktamar Al Washliyah ke-xv Pekanbaru Riau. Wajah Islam.

Jamil, Bahrum. (1992). Batu demi batu di bawah panas yang terik UISU kami dirikan. Ma'had Muallimin Al Washliyah-Teladan.

Karim, M. Husein Abd. (ed.). (1951). 21 tahun Al Dj. Washlijah 30 nov. 1930-30 nov. 1951. Pustaka Al Washlijah.

Koto, Alaidin. (2016). Buya KH. Sirajuddin Abbas: Profil dan pemikiran politiknya tentang Indonesia. Rajawali Pers.

Kuntowijoyo. (2013). Pengantar ilmu sejarah. Tiara Wacana.

Lubis, Adnan. (1954). Kissah isra' dan mi'raj. Islamiyah.

Lubis, Adnan. (1962). Tafsir al-Qur'anul karim: Surat Jaasin ajat 1-83. Islamiyah.

Lubis, Adnan. (1967). Tafsir djuzu’ amma. Islamiyah.

Lubis, M. Arsjad Thalib. (1967). Kedudukan kepala negara R.I. ditinjau dari sudut hukum Islam. Dalam Kedudukan kep. negara dalam hukum Islam. Jajasan Balai Penerbitan Islam Medan.

Lubis, M. Arsjad Thalib. (1983). Perbandingan agama Kristen dan Islam. Islamiyah. Lubis, Yusuf Ahmad. (1973). Ketuhanan dan salib. Masa. 
Islamijah: Journal of Islamic Social Sciences, Volume 1, Number 1, January 2020: 1-25

Madjallah Kebenaran. (1945). Boekoe peringatan kongres Islam Soematera, $1-4$ moeharram 1365 (6-9 des. 1945). Madjallah Kebenaran.

Majelis Ulama Sumatera Utara. (1982). Fatwa dan hukum tentang jema'ah Ahmadiyah Qadiyany. Majelis Ulama Sumatera Utara.

Noer, Deliar. (1980). Gerakan modern Islam di Indonesia, 1900-1942. LP3ES.

Noer, Deliar. (1987). Partai Islam di pentas nasional. Grafiti Pers.

Pengoeroes Besar Djam'ijatoel Washlijah. (1936, January). Keringkasan riwajat hasil dan oesaha pekerdjaan Al Djamijatoel Washlijah selama 5 tahoen moelai tanggal 30 november 1930-30-11-1935. Medan Islam.

Reid, Anthony. (2014). The blood of the people: Revolution and the end of traditional rule in Northern Sumatra. National University of Singapore.

Sekretariat DPR-GR. (1983). Seperempat abad dewan perwakilan rakyat republik Indonesia. Sekretariat DPR-GR.

Sjamsuddin, Udin atau Oedin Sjamsoeddin. (1941). Sendjata moeballigh Islam. Boekhandel Islamijah.

Sjamsuddin, Udin. (1956). Chutbah pengurus besar memperingati ulang tahun Al Djamijatul Washlijah seperempat abad 30 november 1930-30 november 1955. Pengurus Besar Al Djamijatul Washlijah.

Sjihab, Abdurrahman. (1934, September). Pangkal kemenangan. Medan Islam.

Sjihab, Abdurrahman. (1934, December). Menjamboet hari raja. Medan Islam.

Sjihab, Abdurrahman. (1934, December). Pangkal kemenangan. Medan Islam.

Sjihab, Abdurrahman. (1935, April). Tarich imam Aboehanifah. Medan Islam.

Sjihab, Abdurrahman. (1935, Mei). Tarich imam Aboehanifah. Medan Islam.

Sjihab, Abdurrahman. (1940). Penoentoen hadji. Boekhandel Islamijah.

Sjihab, Abdurrahman. (1950, Nopember). Hari peringatan ulang tahun ke xx Al Djamijatul Washlijah 30 nopember 1930-30 nopember 1950. Medan Islam.

Sjihab, Abdurrahman. (1951). Memperingati Al Djam'ijatul Washlijah 21 tahun 30 november 1930-30 november 1951. Dalam M. Husein Abd. Karim (ed.). (1951), 21 tahun Al Dj. Washlijah 30 nov. 1930-30 nov. 1951. Pustaka Al Washlijah. 
Ulama Mandailing Awal Abad ke-20: ... (Ja'far)

Sjihab, Abdurrahman. (1951). Pandangan terhadap kementerian agama. Dalam M. Husein Abd. Karim (ed.). (1951), 21 tahun Al Dj. Washlijah 30 nov. 1930-30 nov. 1951. Pustaka Al Washlijah.

Sulaiman, Nukman (ed.). (1956). Peringatan Al Djamijatul Washlijah 1/4 abad 30 nopember 1930-30 nopember 1955. Pengurus Besar Al Djamijatul Washlijah.

Syahnan, M., Asrul, A., \& Ja'far, J. (2019). Intellectual network of Mandailing and Haramayn muslim scholars in the mid-19th and early 20th century. TEOSOFI: Jurnal Tasawuf dan Pemikiran Islam, 9(2), 257-281. https://doi.org/ 10.15642/teosofi.2019.9.2.257-281

Tanjung, Muaz. (2012). Maktab Islamiyah Tapanuli 1918-1942: Menelusuri sejarah pendidikan Islam awal abad ke-20 di Medan. IAIN Press.

Tanjung, Muaz. (2018). Dinamika lembaga pendidikan Islam di Sumatera Timur pada tahun 1892-1942. (Ph.D's. Thesis: Pascasarjana Universitas Islam Negeri Sumatera Utara Medan.

Thahir bin Shaleh al-Djazairy. (1968). Sendi iman (Mutiara ilmu kalam), terjemahan Nukman Sulaiman. Islamyah.

Toer, Pramoedya, et al. (1999). Kronik revolusi Indonesia: 1 (1945). Gramedia.

Toer, Pramoedya, et al. (1999b). Kronik revolusi Indonesia: 2 (1946). Gramedia.

Wahid, Ramli Abdul. (2011). Kupas Tuntas Ajaran Ahmadiyah. Medan: LP2IK.

Wawancara, Ahmad Faisal AR. Syihab, 7 Maret 2018 di Medan.

Wawancara, Fatimah Zahara, 7 Maret 2018 dan 8 April 2020 di Jakarta.

Ya'cub, Abubakar dan Muhammad Nuh Hudawi. (1969). Peladjaran landjutan agama Islam. Jilid 1. Islamyah.

Ya'cub, Abubakar. (1975). Jenis-jenis sembahyang sunat. Islamiyah.

Yunus, Mahmud. (1993). Sejarah pendidikan Islam di Indonesia. Hidakarya Agung. 